\title{
TYPES OF GEOECOSYSTEMS OF THE LOBELIA LAKES OF THE TRICITY AREA
}

\author{
Maciej MarkowsKi, MoniKa KwiDZIŃSKA \\ Department of Limnology, University of Gdańsk, Poland
}

Manuscript received: July 1, 2014

Revised version: January 15, 2014

\begin{abstract}
Markowski M., KwidzińsKa M., 2015. Types of geoecosystems of the lobelia lakes of the Tricity area. Quaestiones Geographicae 34(1), Bogucki Wydawnictwo Naukowe, Poznań, pp. 15-25, 6 tables, 2 fig. DOI 10.1515/quageo-2015-0002, ISSN 0137-477X.

AвSTRACT: In the years 2009-2010 limnological research was carried out on 13 lobelia lakes of the Tricity metropolitan area. These lakes, of unique value not only on the scale of the country, are undergoing degradation due to increasing anthropogenic pressure. Grade of degradation of these lakes, depends on geoecosystem type, which they are representing. Geoecosystem type of the lake, defines the rate of natural eutrophication of reservoir. In this article types of geoecosystems of analysed lobelia lakes where defined in accordance with the guidelines of Bajkiewicz-Grabowska $(1981,1983,1985,1987,2002)$. The obtained results indicate that only one of the analysed lakes (Zawiat Lake) is likely to retain a low trophic level. Four lakes (Głębokie, Kamień, Borowo, Techlinko) represent geoecosystems with a moderate rate of natural eutrophication. The remaining of the analysed lobelia lakes are threatened with fast water eutrophication, which is demonstrated by a high catchment vulnerability to activate areal load, and a low resistance of the lakes (resulting from their natural properties) to external supply. The obtained results correspond to field measurements and make it possible to indicate actions aimed at protecting the group of the analysed lobelia lakes.
\end{abstract}

KEY wORDS: lobelia lake, geosystem, geoecosystem, elementary geosystem, vulnerability and resistance to degradation

Address of the corresponding author: Maciej Markowski, Department of Limnology, University of Gdansk, Poland;

e-mail: geomma@ug.edu.pl

\section{Introduction}

The natural environment is a complex system, yet when it operates without anthropogenic pressures, it functions perfectly. Increasing human activity causes a degradation of particular components, and the increasing degradation has triggered a growing pro-ecological awareness in the public. It is therefore becoming crucial to undertake effective steps to prevent further deterioration in the quality of the environment. One of the most basic actions is to collate information in order to determine the level of tolerance of particular geographical features. Basically, each feature is a system in itself, as it is composed of elements bound by mutual relationships (Bertalanffy 1984; Buslenko et al. 1979). The issues of boundaries and the territorial character of natural systems have been repeatedly analysed in the literature on the subject (Chojnicki 1988; Przewoźniak 1991; Kostrzewski 1991; Richling 1992; Kistowski 1993; Czochański 1998; Staszek 1999; Richling and Lechnio 2005).

Natural landscape units in which there is a continuous flow of energy and circulation of matter are called geoecosystems in landscape geoecology (Kostrzewski 1991, 1993). An example of such a geoecosystem is a lake geoecosystem, i.e. a natural landscape feature comprised of a lake ecosystem together with the catchment supplying it 
with matter. The operation of a lake geoecosystem depends mainly on: climatic conditions, hydrological conditions, features of the physical and geographical environment of the catchment and limnological features (abiotic and biotic) of the reservoir. The operation of a lake geoecosystem is based on the continuous transport of matter from the catchment and its accumulation in the lake. The basic means of transport of the various forms of matter in this system is water. The relationship between the catchment and the lake determine the relative stability of the lake geoecosystem and evolution rate of the reservoir, whose symptoms include slow changes in the fertility of its waters. Hence the rate of natural eutrophication of lake waters resulting from the natural conditions of the water ecosystem and its alimentation area (catchment) determines the type of a lake's geoecosystem, which in turn expresses the quality of the water ecosystem structure and the manner of its functioning.

Intensified anthropopressure leads to degradational transformations of lake geoecosystems, which consists of rapid, negative and lasting changes to the limnological properties of lakes when their adaptability range has been exceeded by external pressure. This problem concerns all water reservoirs, hence also those of particular natural value. This group includes lobelia lakes, i.e. such lakes where characteristic plant species (isoetids) occur individually and collectively: water lobelia (Lobelia dortmanna), lake quillwort (Isoëtes lacustris), spring quillwort (Isoëtes echinospora), shoreweed (Littorella uniflora), alternate-flowered water-milfoil (Myriophyllum alterniflorum), the more rarely found floating water plantain (Luronium natans) (including Wilk-Woźniak et al. 2012). 175 such lakes have been identified in Poland (Gos and Bociąg 2003). Increasing anthropopressure can soon cause deterioration of physical-chemical properties in lobelia lakes water. As a consequence of excessive eutrophication the number of eutrophicated lobelia lakes will increase and in case of progressive waters degradation, the number of degradated lobelia lakes will increase, too (Kraska i Piotrowicz 2000). Conscious action for lobelia lakes protection, requires action that aim identification of degradation reason. To protect these lakes successfully the rate of natural eutrophication should be defined by determination of which environmental conditions foster their water eutrophication. The course of the eutrophication process of a lake is determined by the mutual relationships among the different components of the geoecosystem. The resultant combination of all the factors fostering eutrophication has a different value for each lake (Bajkiewicz-Grabowska 2007).

\section{Methods and area of research}

In order to assess the rate of natural eutrophication of a lake, it is necessary to include relationship between it and its catchment, both immediate and total. Of the available methodological studies, for the purposes of the assessment of natural eutrophication of a lake and in consequences type of geoecosystem, the method by BajkiewiczGrabowska (1981, 1983, 1985, 2002) was applied. It consists of an evaluation of the catchment's vulnerability to the activation of an areal load and the transport of it to the lake, and the resistance of the lake to the impact of the catchment (Fig. 1).

Designation of parameters to this evaluation, required collecting of proper research material, which was obtained during fieldworks led in 20092010. These fieldworks included fundamental limnological measurements (vertical distribution of characteristics which reflect natural environment properties, that is: water temperature, content and oxygen saturation, conductivity, $\mathrm{pH}$ ). In collected lake water samples, by using methodology of

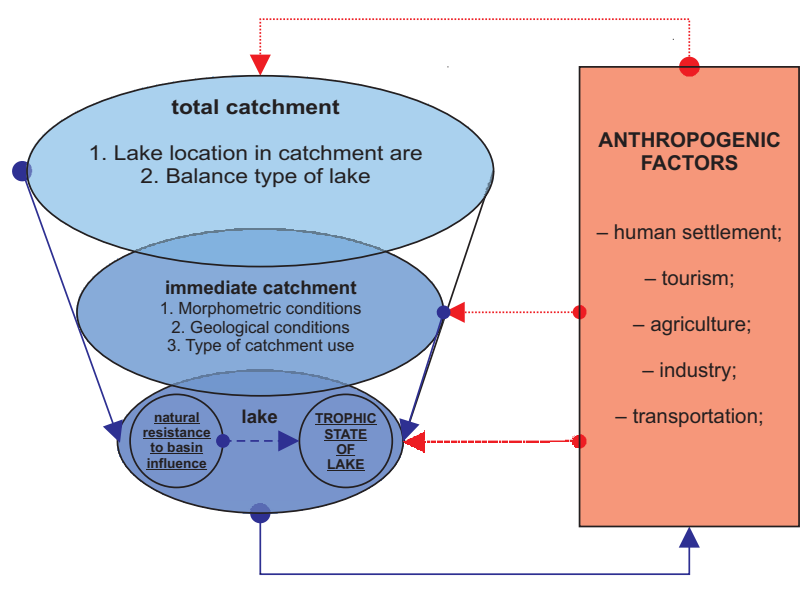

Fig. 1. Mutual impact of a loop system: anthropopressure-catchment-lake (Bajkiewicz-Grabowska (2002), modified) 
quantitative analysis colorimetric analysis which is based on Lambert-Beer law, concentration of biogenic substances was denoted.

With the aim of updating and supplementing morphometric data, bathymetric charts were performed using a multibeam echo sounder for each lakes. A highly valuable material proved to be a community interview with the lease-holders of the lakes covered by this study. They provided information on the earlier sanitary and epidemic condition of the lakes.

The research procedure also included a survey of cartographic materials: topographic maps (1:10 000), orthophotomaps (land use), hydrographic photographs, geological maps (SMGP in scale 1:50 000).

The information on the resources of indicator plants' populations was mainly drawn from the studies by Szmeja (1992, 1993, 1996), Bociąg (1999), Gos i Bociąg (2003). Additionally, consultation was carried out with the main executor of the project "Preparation of a lobelia lakes base of the Pomeranian administrative region", funded by the Provincial Fund for Environment Protection and Water Management in Gdańsk.

13 lobelia lakes situated closest to the Tricity metropolitan area were analysed. These are the lakes: Karlikowskie (Karlikowo), Sitno, Głębokie, Techlinko (Techlinka), Otalżyno, Wysoka (Wycztok), Jelonek, Brzeżonko, Kamień, Borowo, Bieszkowickie, Zawiat and Osowskie, which is located the closest to the Tricity metropolitan area (Fig. 2). They are elements of the Kashubian Lakeland landscape (Table 1), hence their drainage basins have a morainic plateau character.

In morphometric terms (Table 2) these lakes are reservoirs of a small area (from 6 ha to 52 ha) and diverse maximum depth (from $3.1 \mathrm{~m}$ to 30.9 $\mathrm{m})$. A majority of them are shallow lakes lacking

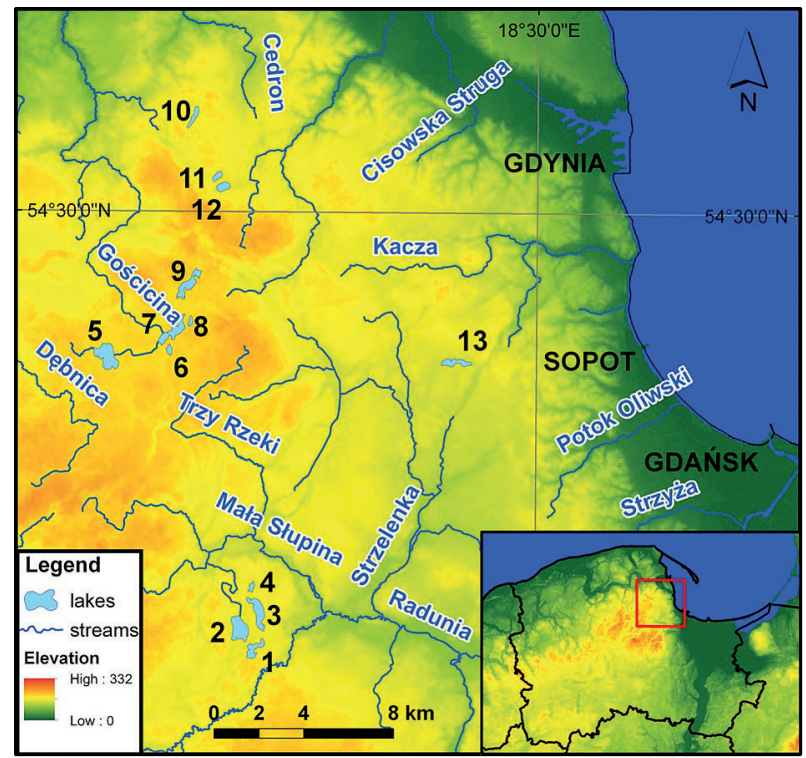

Fig. 2. Location of analysed lakes 1 - Karlikowskie; 2 - Sitno; 3 - Głębokie; 4 - Techlinko; 5 Otalżyno; 6 - Jelonek; 7 - Wysoka; 8 - Brzeżonko; 9 - Kamień; 10 Borowo; 11 - Bieszkowickie; 12 - Zawiat; 13 - Osowskie

a stable summer stratification. Only lakes Głębokie, Kamień, Borowo and Zawiat are stratified in the summer.

\section{Research results and discussion}

In accordance with the adopted method of determination of a lake geoecosystem type, the catchment vulnerability to the activation of an areal load and the likelihood of it reaching the lake and the resistance of the lake to catchment pressure was assessed (Bajkiewicz-Grabowska 2002).

The degree of influence of the total catchment on a lake was estimated on the basis of the Ohle index (lake index) of the balance type of lake (en-

Table 1. Lake groups with classification into particular units of physical-geographical division of the Kashubian Lakeland

\begin{tabular}{|c|l|l|l|}
\hline Group & \multicolumn{1}{|c|}{ Lakes } & \multicolumn{1}{|c|}{$\begin{array}{c}\text { Division according to Gacki } \\
\text { and Szukalski (1979) }\end{array}$} & \multicolumn{1}{|c|}{$\begin{array}{c}\text { Division according to Przewoźniak } \\
\text { (1985) }\end{array}$} \\
\hline 1 & $\begin{array}{l}\text { Karlikowskie, Sitno, Głębokie, } \\
\text { Techlinko }\end{array}$ & $\begin{array}{l}\text { Sianowsko-Dzierżąskie Lakeland } \\
\text { Brzeżonko, Kamień }\end{array}$ & $\begin{array}{l}\text { Kiełpińsko-Ramlejska Morainic } \\
\text { Plateau }\end{array}$ \\
\hline 2 & Borowo, Bieszkowickie, Zawiat & $\begin{array}{l}\text { Łebnowsko-Kielnowskie Hum- } \\
\text { mocks and Hills }\end{array}$ & $\begin{array}{l}\text { Szemudzko-Pomieczyńska Morainic } \\
\text { Plateau }\end{array}$ \\
\hline 4 & Osoinic Plateau & $\begin{array}{l}\text { Gniewowsko-Bieszkowicka Morainic } \\
\text { Plateau }\end{array}$ \\
\hline
\end{tabular}


Table 2. Chosen morphometric parameters

\begin{tabular}{|c|c|c|c|c|c|c|c|c|}
\hline \multirow{3}{*}{ Lake } & \multicolumn{2}{|c|}{ Geographic coordinates } & \multirow{3}{*}{$\begin{array}{c}\text { Absolute } \\
\text { altitude }\end{array}$} & \multicolumn{2}{|c|}{ Depth } & \multirow{3}{*}{$\begin{array}{l}\text { Volume } \\
{\left[10^{3} \cdot \mathrm{m}^{3}\right]}\end{array}$} & \multirow{3}{*}{$\begin{array}{c}\text { Area } \\
{[\mathrm{ha}]}\end{array}$} & \multirow{3}{*}{$\begin{array}{c}\text { Length of } \\
\text { shoreline } \\
{[\mathrm{m}]}\end{array}$} \\
\hline & longitude & latitude & & maximum & mean & & & \\
\hline & \multicolumn{2}{|c|}{$\left[^{\circ}\right]$} & & \multicolumn{2}{|c|}{$[\mathrm{m}]$} & & & \\
\hline Karlikowskie & $18^{\circ} 18^{\prime} 28.46^{\prime \prime}$ & $54^{\circ} 19^{\prime} 30.14^{\prime \prime}$ & 158.9 & 6.5 & 2.5 & 777.5 & 29.67 & 3493 \\
\hline Sitno & $18^{\circ} 17^{\prime} 51.73^{\prime \prime}$ & $54^{\circ} 19^{\prime} 58.99^{\prime \prime}$ & 159.9 & 8.3 & 2.7 & 1609.2 & 62.98 & 3629 \\
\hline Głębokie & $18^{\circ} 18^{\prime} 37.51^{\prime \prime}$ & $54^{\circ} 20^{\prime} 23.48^{\prime \prime}$ & 158.2 & 21.8 & 9.2 & 4717.6 & 52.07 & 4477 \\
\hline Techlinko & $18^{\circ} 18^{\prime} 21.01^{\prime \prime}$ & $54^{\circ} 20^{\prime} 59.66^{\prime \prime}$ & 158.5 & 3.1 & 1.9 & 150.1 & 8.06 & 1361 \\
\hline Otalżyno & $18^{\circ} 12^{\prime} 17.21^{\prime \prime}$ & $54^{\circ} 26^{\prime} 30.32^{\prime \prime}$ & 192.7 & 5.9 & 1.2 & 998.5 & 80.73 & 4614 \\
\hline Jelonek & $18^{\circ} 14^{\prime} 51.65^{\prime \prime}$ & $54^{\circ} 26^{\prime} 40.49^{\prime \prime}$ & 192.4 & 3.6 & 1.6 & 134.5 & 8.43 & 1229 \\
\hline Wysoka & $18^{\circ} 15^{\prime} 00.67^{\prime \prime}$ & $54^{\circ} 27^{\prime} 07.40^{\prime \prime}$ & 191.7 & 7.1 & 1.8 & 916.1 & 50.63 & 5093 \\
\hline Brzeżonko & $18^{\circ} 15^{\prime} 43.50^{\prime \prime}$ & $54^{\circ} 27^{\prime} 21.66^{\prime \prime}$ & 191.9 & 4.7 & 1.9 & 139.9 & 5.93 & 1142 \\
\hline Kamień & $18^{\circ} 15^{\prime} 37.49^{\prime \prime}$ & $54^{\circ} 28^{\prime} 15.47^{\prime \prime}$ & 192.4 & 30.9 & 5.8 & 2749.5 & 46.93 & 5248 \\
\hline Borowo & $18^{\circ} 15^{\prime} 46.62^{\prime \prime}$ & $54^{\circ} 32^{\prime} 17.26^{\prime \prime}$ & 163.3 & 9.2 & 3.4 & 560.9 & 16.20 & 2383 \\
\hline Bieszkowickie & $18^{\circ} 16^{\prime} 46.41^{\prime \prime}$ & $54^{\circ} 30^{\prime} 51.42^{\prime \prime}$ & 153.5 & 6.8 & 2.7 & 291.1 & 10.75 & 1355 \\
\hline Zawiat & $18^{\circ} 17^{\prime} 00.99^{\prime \prime}$ & $54^{\circ} 30^{\prime} 36.32^{\prime \prime}$ & 153.8 & 15.2 & 6.5 & 1179.7 & 18.10 & 1697 \\
\hline Osowskie & $18^{\circ} 26^{\prime} 39.40^{\prime \prime}$ & $54^{\circ} 26^{\prime} 25.61^{\prime \prime}$ & 144.5 & 8.7 & 2.9 & 848 & 28.89 & 3431 \\
\hline
\end{tabular}

dorheic, exorheic and flow-through). The lake index (Ohle), understood a quotient of total lake catchment and area of the lake, informs of the size of the area which aliments the lake. The lower the value of this parameter, the more favourable situation the reservoirs is in. The location of the analysed geoecosystems of lobelia lakes in the system of surface outflow results in the fact that their total catchments often correspond to immediate catchments. Exceptions are the catchments of lakes Głębokie and Wysoka. The greatest impact of the total catchment (highest lake index) occurs in the small Lake Brzeżonko (LI=47; Table 3).
The balance type of a lake determines the potential of biogenic matter supply to the reservoir and its discharge from it. Endorheic lakes are a trap for biogenic matter, while exorheic lakes mainly export the matter out of the geoecosystem, like flow-through lakes, which are additionally subject to the "washing out" process. The balance type of analysed lobelia lakes was determined on the basis of observations and hydrometric measurements carried out over a few years. On the basis of the length of the operation of the inflow and outflow from the lakes, it was assumed that Lake Wysoka was a flow-through

Table 3. Point assessment of catchment vulnerability of lobelia lakes of Tricity area to matter supply to lakes

\begin{tabular}{|c|c|c|c|c|c|c|c|c|c|c|c|c|c|c|c|c|}
\hline \multirow{3}{*}{ Lake name } & \multicolumn{7}{|c|}{ Assessment parameters } & \multicolumn{7}{|c|}{ Number of points } & \multirow[b]{3}{*}{ mean } & \multirow{3}{*}{$\begin{array}{l}\text { Vul- } \\
\text { nera- } \\
\text { bility } \\
\text { group }\end{array}$} \\
\hline & LI & BT & DD & CS & EA & G & U & LI & BT & DD & CS & EA & G & $\mathrm{U}$ & & \\
\hline & {$[-]$} & {$[-]$} & $\begin{array}{l}{[\mathrm{km}} \\
\left.\mathrm{m}^{-2}\right]\end{array}$ & $\begin{array}{c}{[\mathrm{m}} \\
\left.\mathrm{m}^{-2}\right]\end{array}$ & [\%] & {$[-]$} & {$[-]$} & {$[-]$} & {$[-]$} & {$[-]$} & {$[-]$} & {$[-]$} & {$[-]$} & {$[-]$} & & \\
\hline Karlikowskie & 6 & En & 0.08 & 24.5 & 18 & $\mathrm{~S}$ & AFB & 0 & 2 & 0 & 3 & 3 & 3 & 3 & 2.0 & 4 \\
\hline Sitno & 4 & Ex & 1.61 & 20.1 & 0 & ST & PFB & 0 & 1 & 3 & 3 & 3 & 1 & 3 & 2.0 & 4 \\
\hline Głębokie & 6 & En & 0.31 & 21.1 & 26 & $\mathrm{~S}$ & PAFSb & 0 & 2 & 0 & 3 & 2 & 3 & 2 & 1.7 & 3 \\
\hline Techlinko & 13 & Ex & 0.10 & 28.7 & 11 & ST & FA & 1 & 1 & 0 & 3 & 3 & 1 & 1 & 1.4 & 2 \\
\hline Otalżyno & 6 & Ex & 2.08 & 10.5 & 18 & $\mathrm{ST}+\mathrm{P}$ & PA & 0 & 1 & 3 & 2 & 3 & 1 & 1 & 1.6 & 3 \\
\hline Jelonek & 7 & En & 0.42 & 18.8 & 1 & $\mathrm{~S}$ & FPASb & 0 & 2 & 0 & 2 & 3 & 3 & 2 & 1.7 & 3 \\
\hline Wysoka & 23 & FT & 1.99 & 15.0 & 24 & TS+P & FPASb & 1 & 3 & 3 & 2 & 2 & 2 & 2 & 2.1 & 4 \\
\hline Brzeżonko & 47 & Ex & 1.59 & 27.4 & 20 & $\mathrm{ST}+\mathrm{P}$ & PFA & 2 & 1 & 3 & 3 & 2 & 1 & 1 & 1.9 & 3 \\
\hline Kamień & 9 & Ex & 1.19 & 19.3 & 13 & $\mathrm{~S}+\mathrm{P}$ & PAFSb & 0 & 1 & 2 & 2 & 3 & 1 & 2 & 1.6 & 3 \\
\hline Borowo & 26 & En & 0.60 & 18.5 & 27 & $\mathrm{~S}$ & $\mathrm{~F}$ & 1 & 2 & 1 & 2 & 2 & 3 & 0 & 1.6 & 3 \\
\hline Bieszkowickie & 12 & En & 0.11 & 32.8 & 39 & $S$ & $\mathrm{~F}$ & 1 & 2 & 0 & 3 & 2 & 3 & 0 & 1.6 & 3 \\
\hline Zawiat & 11 & En & 0.47 & 56.0 & 49 & $\mathrm{~S}$ & $\mathrm{~F}$ & 1 & 2 & 0 & 3 & 1 & 3 & 0 & 1.4 & 2 \\
\hline Osowskie & 10 & En & 0.18 & 22.7 & 2 & TS & PAB & 1 & 2 & 0 & 3 & 3 & 2 & 3 & 2.0 & 4 \\
\hline
\end{tabular}

Key: LI - Ohle index (lake index); BT - balance type of lake (FT - flow-through, Ex - exorheic, En - endorheic); DD - drainage density; CS - catchment slope; EA - endorheic areas; G - geological structure of catchment ( $\mathrm{S}$ - sand, T - till, P - peat); U - catchment use (F - forest, Aagriculture, $\mathrm{P}$-pasture, B - building development, $\mathrm{Sb}$ - summer building development) 
reservoir, and lakes Sitno, Techlinko, Otalżyno, Brzeżonko and Kamień were exorheic lakes. The remaining analysed lobelia lakes are endorheic.

The immediate catchment of a lake actively contributes to the areal and point supply of biogenic matter to the reservoir. The factor which majorly distinguishes the rate of areal outflow is the degree of the slope grade expressed as a mean slope of the catchment actively participating in lake alimentation. It is calculated as the quotient of the difference of altitude of a given catchment and the square root of its area. The immediate catchments of the lobelia lakes of the Tricity vicinity of a small area, up to $5 \mathrm{~km}^{2}$, are characterised by their relatively large height differences, reaching up to $45 \mathrm{~m}$ (Brzeżonko), hence the mean grades in their immediate catchments are considerable and ranges from $10.5 \%$ (Otalżyno) up to $56.0 \%$ o (Zawiat) (Table 3). The least topographically diverse (height differences of $14 \mathrm{~m}$ ) is the catchment of Lake Otalżyno.

The formation of areal outflow occurs in the part of the immediate catchment from which endorheic areas (sort of buffers arresting areal loads) have been excluded. The higher the proportion of endorheic area to the immediate catchment, the smaller its impact on the reservoir. The location of the analysed lobelia lakes on a morainic plateau results in the fact that considerable parts of their catchments are taken up by endorheic areas. Their percentage ranges from $0 \%$ (Sitno) up to $49 \%$ (Zawiat). The percentage of endorheic areas of the catchments of 7 lakes (Karlikowskie, Sitno, Techlinko, Otalżyno, Jelonek, Kamień, Osowskie) is below $20 \%$ (Table 3 ).

The rate of biogenic matter transported to a lake is influenced directly by the river network density in the immediate catchment of the reservoir. The higher the river network density, the higher chance of the direct supply of areal loads into the lake. The lobelia lakes of the Tricity area reveal a considerable diversity in terms of the tributaries in their catchments. Over a half of the analysed lake catchments (Table 3), have a low river network density $\left(<0.5 \mathrm{~km} \mathrm{~km}^{-2}\right)$. The highest number of watercourses occur in the catchments of Lakes Otalżyno, Wysoka, Sitno and Brzeżonko. Tributaries to lakes, in the case of heavy pollution of their waters, constitute one of the most serious degradational threats for lakes.
The ability of a catchment to activating a areal load depends on the manner of its use. Estimating the value of the biogenic substances supply into a lake from areal sources is very difficult. Hence in the literature there are a number of indicators that attempt to establish the relationship between the type of use of the catchment and the value of the biogenic substances load leaving it (Szyper, Zaniewska 1984; Kajak 1994; Kudelska, Cydzik, Soszka 1994). Yet, most classifications are based on gradation, where the highest contributors to the surface runoff of biogenic substances are come from built-up areas and arable fields. In the applied method, the assessment of the catchment as a matter supplier has a qualitative character (Bajkiewicz-Grabowska 1985). The lakes, in whose immediate catchments the structure of their use has the least impact on the eutrophication rate are: Borowo, Zawiat and Bieszkowickie. The domination of forests in these catchments ranges from 88 to $96 \%$. Particularly disadvantageous conditions are represented by the structure of use of the catchments of lakes Karlikowskie, Sitno as well as Osowskie, with a high percentage of agricultural areas together with a considerable proportion of built-up areas.

Another threat for lakes may come from ground waters "transporting" biogenic compounds which arrive together with infiltrating atmospheric precipitation. Defining the type of surface formations and soil conditions of a catchment makes it possible to determine the ground permeability and thus the conditions of the matter transportation to ground waters. The highest effective infiltration coefficient characterises gravel-sand formations, the lowest - tills, clays and silts (Pazdro, Kozerski 1990). The higher the effective infiltration coefficient, the higher the permeability of the ground, hence the more favourable conditions for the migration of biogenic compounds into ground waters. The highest $(100 \%)$ percentage of sands occur in the catchment of Lake Karlikowskie. Similar infiltration conditions occur in the catchments of lakes Głębokie (86\% of sand formations), Jelonek (98\%), Borowo (85\%), Bieszkowickie (84\%) and Zawiat (78\%). Worse infiltration conditions occur in the catchments of lakes Sitno, Techlinko, Otalżyno, Brzeżonko and Kamień. A certain barrier for the migration of biogenic matter in the catchments of these lakes are till formations (43-51\%). Worth 
mentioning in this group is the catchment of Lake Kamien, where the buffer-barrier zone is made of peats. Kistowski (1996), however, enumerates situations when a long journey for the nutrients that infiltrate through the geological ground is more favourable in terms of the cleanliness of a lake than the occurrence of poorly permeable or impermeable formations.

The application of the system for the assessment of a catchment as a supplier of matter to the lobelia lakes of the Tricity area revealed a serious threat to these reservoirs from their immediate surroundings. Out of the thirteen analysed lakes, the catchments of only two lakes (Techlinko and Zawiat) are characterised by a small vulnerability to the activation of a biogenic matter load (vulnerability group 2). The catchment conditions of these reservoirs show there a small chance of the matter reaching the lakes. The most serious threat to Lake Techlinko from the catchment is high ground slopes (up to $29 \%$ ) and a small (11\%) percentage of endorheic areas. The lake receives no inflow, thanks to which the supply of nutrients from point sources is limited. Moreover, in the southern part of its basin there is an outflow, which facilitates the discharge of matter accumulated in the reservoir. The immediate catchments of lakes Zawiat and Techlinko are characterised by a very high mean grade, with the highest value being $56 \%$. The catchments of these lakes are sandy (sand formations constitute over $80 \%$ of their area) and $96 \%$ forested. Such a forest-sand composition means that the high infiltration capacity is compensated by a small quantity of biogenic matter supplied from forest areas. The remaining 11 lobelia lakes are characterised by a moderate (vulnerability group $3-7$ lakes) and high (vulnerability group $4-4$ lakes) catchment pressure on the lake. The parameters which foster the pressure are high ground slopes and small proportions of endorheic areas.

In the assessment of a lake geoecosystem type, a lake's resistance to the impact of its catchment is taken into consideration as well. The same impact of a catchment on a lake gives different results in the case of lakes with a high natural resistance to eutrophication than in those with a high vulnerability to external impact. The eutrophication rate is also different when a lake with a certain vulnerability to degradation is influenced by a catchment heavily vulnerable to the activation of areal loads and supplies to the lake than when the catchment has a limited capacity of matter supply.

Following the adopted method (Bajkiewicz-Grabowska 1981, 1983, 1985, 2002), the resistance of a lake to its catchment impact is determined by the following parameters: the mean depth of the lake, the quotient of the lake capacity and its shoreline length, the quotient of the area of active bottom and volume of epilimnion, the percentage of water stratification, the intensity of water exchange and the Schindler index, i.e. the quotient of the total catchment area of the lake and its volume.

Most of the analysed lobelia lakes (10) are shallow reservoirs, hence they are less resistant to fertilisation than deep reservoirs (Table 4). The mean depths of these lakes are up to $3.4 \mathrm{~m}$. Particularly poorly resistant to the catchment impact is Lake Otalżyno, relatively big (80.73 ha) and shallow (mean depth $1.2 \mathrm{~m}$ ). The most favourable depth relationships occur in Lake Głębokie, with a mean depth of over $9 \mathrm{~m}$.

The depth relationships of a lake, and hence also the shape of the lake basin determine the water potential of a given reservoir, expressed as lake capacity. In turn, the quotient of lake capacity and shoreline length determines a lake's resistance to eutrophication. For the lobelia lakes of the Tricity area this parameter has values below 1 , which means that they are not resistant to external impact (Table 4).

The resistance of lakes to their catchment's impact is also weakened by the low intensity of "washing out", expressed as the quotient of mean annual outflow from the lake and lake capacity. Poor horizontal water exchange conditions in the analysed reservoirs are caused by a small number of watercourses discharging biogenic substances out of the lake geoecosystem. This results in a complete lack of water horizontal exchange recorded in endorheic lakes. In hydrologically active reservoirs (Sitno, Techlinko, Kamień, Otalżyno, Wysoka, Brzeżonko) the exchange is low $(\leq 1.4)$.

The resistance of reservoirs can also be established on the basis of their mictic type. Those shallow reservoirs mentioned above belong to polymictic lakes (Karlikowskie, Sitno, Techlinko, Otalżyno, Jelonek, Wysoka, Brzeżonko, Bieszkowickie, Osowskie) without a stable stratification, in which the water mass is mixed many 
Table 4. Point assessment of resistance of lobelia lakes of Tricity area to supply of matter from catchment (based on field measurements)

\begin{tabular}{|c|c|c|c|c|c|c|c|c|c|c|c|c|c|c|}
\hline \multirow{3}{*}{ Lake } & \multicolumn{6}{|c|}{ Assessment parameters } & \multicolumn{6}{|c|}{ Number of points } & \multirow[b]{3}{*}{ mean } & \multirow{3}{*}{$\begin{array}{c}\text { Resist- } \\
\text { ance } \\
\text { cate- } \\
\text { gory }\end{array}$} \\
\hline & MD & $\mathrm{V} / \mathrm{L}$ & AEV & $\mathrm{S}$ & FR & SI & MD & $\mathrm{V} / \mathrm{L}$ & $\mathrm{AEV}$ & $\mathrm{S}$ & FR & SI & & \\
\hline & {$[\mathrm{m}]$} & {$\left[10^{3} \mathrm{~m}^{3} \mathrm{~m}^{-1}\right]$} & {$\left[\mathrm{m}^{2} / \mathrm{m}^{3}\right]$} & {$[\%]$} & {$[-]$} & {$\left[\mathrm{m}^{-1}\right]$} & {$[-]$} & {$[-]$} & {$[-]$} & {$[-]$} & {$[-]$} & {$[-]$} & & \\
\hline Karlikowskie & 2.5 & 0.22 & 0.38 & 0.0 & 0.00 & 2.3 & 3 & 3 & 3 & 3 & 3 & 0 & 2.5 & IV \\
\hline Sitno & 2.7 & 0.44 & 0.51 & 0.0 & 0.18 & 1.4 & 3 & 3 & 3 & 3 & 3 & 0 & 2.5 & IV \\
\hline Głębokie & 9.2 & 1.05 & 0.09 & 59.8 & 0.00 & 0.6 & 1 & 2 & 0 & 0 & 3 & 0 & 1.0 & II \\
\hline Techlinko & 1.9 & 0.11 & 0.54 & 0.0 & 0.45 & 7.0 & 3 & 3 & 3 & 3 & 3 & 0 & 2.5 & IV \\
\hline Otalżyno & 1.2 & 0.22 & 0.85 & 0.0 & 1.04 & 4.7 & 3 & 3 & 3 & 3 & 2 & 0 & 2.3 & III \\
\hline Jelonek & 1.6 & 0.11 & 0.63 & 0.0 & 0.00 & 4.2 & 3 & 3 & 3 & 3 & 3 & 0 & 2.5 & IV \\
\hline Wysoka & 1.8 & 0.18 & 0.63 & 0.0 & 1.40 & 12.7 & 3 & 3 & 3 & 3 & 2 & 1 & 2.5 & IV \\
\hline Brzeżonko & 1.9 & 0.12 & 0.42 & 0.0 & 1.31 & 19.7 & 3 & 3 & 3 & 3 & 2 & 1 & 2.5 & IV \\
\hline Kamień & 5.8 & 0.52 & 0.14 & 59.9 & 0.17 & 1.6 & 1 & 3 & 1 & 0 & 3 & 0 & 1.3 & II \\
\hline Borowo & 3.4 & 0.24 & 0.18 & 54.1 & 0.00 & 7.6 & 2 & 3 & 2 & 0 & 3 & 0 & 1.7 & II \\
\hline Bieszkowickie & 2.7 & 0.21 & 0.37 & 0.0 & 0.00 & 4.3 & 3 & 3 & 3 & 3 & 3 & 0 & 2.5 & IV \\
\hline Zawiat & 6.5 & 0.70 & 0.12 & 50.8 & 0.00 & 1.6 & 1 & 3 & 1 & 0 & 3 & 0 & 1.3 & II \\
\hline Osowskie & 2.9 & 0.25 & 0.34 & 0.0 & 0.00 & 3.6 & 3 & 3 & 3 & 3 & 3 & 0 & 2.5 & IV \\
\hline
\end{tabular}

Key: MD - mean depth; V/L - lake volume to shoreline length; AEV - areas of active bottom to epilimnion volume; S - stratification; FR flushing rate; SI - Schindler index

times a year. This lack of stratification leads to the high productivity of the reservoirs, thus lowering their resistance to eutrophication. The area of active bottom in such lakes covers the whole bottom of the lake basin, thus enabling recirculation of biogenic substances from sediments into the water mass. Both the low percentage of stratified waters and the high value of the coefficient (expressed as the quotient of the active bottom area and lake capacity) significantly decreases the lake resistance to eutrophication.

Four lakes (Głebokie, Kamien, Borowo, Zawiat) belong to the class of dimictic lakes, in which the water mass is mixed two times a year, and in summer a stable thermal stratification occurs. Based on fieldworks the percentage of stratified waters (metalimnion together with hypolimnion) in these reservoirs ranges from 51 to $60 \%$. The productivity of these water ecosystems is thus definitely lower than non-stratified lakes. The presence of summer thermal stratification restricts the occurrence of the active bottom to the region of the epilimnion layer. The recirculation of biogenic substances from sediments to the waters of epilimnion is thus limited, which raises lake resistance to degradation.

The last parameter applied to the system of assessment of degradation resistance of lakes is the Schindler index. It is the quotient of the area receiving pollutants (the total catchment) and the quantity of water collected in the reservoir which dilutes them. The total catchments of the analysed lobelia lakes are so small that the Schindler index for all the analysed lakes is low (0.6-19.7 $\left.\mathrm{m}^{2} \mathrm{~m}^{-3}\right)$.

The arithmetic mean of points which were assigned to the reservoirs in the analysis of particular factors influencing their eutrophication resistance, distinguishes two groups of lakes. This division corresponds directly to the types of thermal and dynamic regimes represented by the analysed lobelia lakes. Deep reservoirs of a dimictic regime type (Głebokie, Kamien, Zawiat, Borowo) have a resistance category of II, thus

Table 5. Types of lake geoecosystems (lake elementary geosystems)

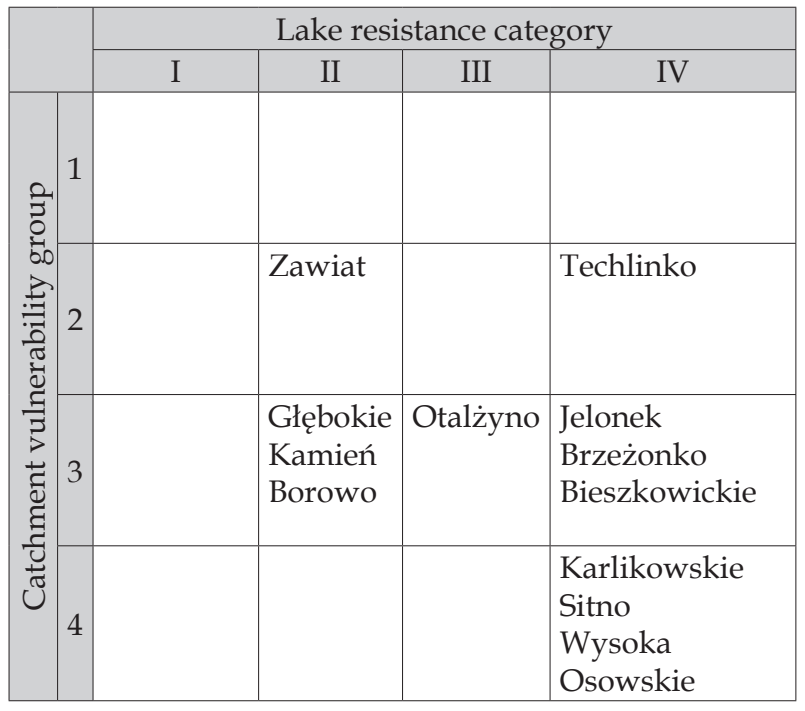


they have medium resistance to external impact (Table 5). These lakes are characterised by a passive hydrological regime resulting in very small water exchange. Additionally, another unfavourable element in this group of lakes is the parameter determining the ratio between lake capacity and its shoreline length. The remaining four analysed features, which are mainly related to the thermal-dynamic regime, increase the resistance of these reservoirs to external influence. Particularly favourable results in this assessment are recorded for the Schindler index which, as indicated by its value, raises the resistance of both dimictic and polymictic lakes. The other group consists of shallow lakes with a polimictic type of thermal-dynamic regime. Their small depth, and thus a lack of stable stratification during the summer, together with the small water exchange in reservoirs give them resistance categories of III and IV. Small resistance (category III) characterises Lake Otalżyno. Non-resistant to catchment impact (resistance category IV) are lakes Karlikowskie, Sitno Techlinko, Jelonek, Wysoka, Brzeżonko, Bieszkowickie and Osowskie.

Given the catchment's vulnerability to the activation and supply of nutrients to a lake, and the resistance of the lake to the reception of the matter, it is possible to determine the lake geoecosystem. Bajkiewicz-Grabowska (2010) distinguished four types of lake geoecosystems.

The first type, in which the lake geoecosystem has a chance of maintaining its trophic state at a lower level. The lake belongs to resistance category I or II and its catchment to vulnerability group 1 or 2 . Among the analysed lobelia lakes of the Tricity area only Lake Zawiat represents this geoecosystem type. It is resistant to external impact (category II) and its catchment is characterised by a low likelihood of activation and supply of nutrients to it (group 2). It should, however, be mentioned that an ill-conceived human activity and influence on this geoecosystem may cause an increase in the eutrophication rate of this lake due to intense environmental pressure. Convenient bathing conditions cause the littoral abundant in Lobelia and Isoëtes lacustris to undergo fast degradation.

The second geoecosystem type, describes a moderate rate of the natural eutrophication of a lake. High catchment pressure, understood as the high likelihood of the activation and supply of biogenous matter to the reservoirs (vulnerability group 3 or 4), is limited by high lake resistance (resistance category I or II). Such a geoecosystem type occurs in the stratified lakes of Głębokie, Kamien and Borowo. The strong natural catchment pressure in the case of Lakes Głębokie and Kamien is strengthened by heavy recreational building development on their shorelines. A serious and immediate threat is this case of inadequate sewage management, resulting in an intensified supply of biogenic substances into the lakes. The quantity of biogenic substances fosters the occurrence of plants more expansive than the indicator species of lobelia lakes. This may result in the rapid disappearance of species especially those occurring in shallower sections of the littoral (Lobelia dortmanna and Litorella uniflora). Lake Borowo, though seriously threatened by catchment impact, seems to be in a much better situation than the two previously mentioned lakes. The forest cover of its catchment is almost $90 \%$ and the only human threat is a small bathing site in the northern part of the lake, unless other radically degrading activities occur in the meantime. In 2010, buildings lacking a sewage system were removed from the northern part of the shore zone of the lake, thus cutting off an inflow of household and municipal sewage.

The third geoecosystem type, like the previous one, determines a moderate rate of natural eutrophication. This type is characterised by favourable catchment conditions (vulnerability group 1 or 2 ), which manifests in a moderate activity of the supply of areal load to the lake. The lake itself shows low resistance to catchment impact (resistance category III or IV). Such a system can be destabilised relatively easily by unfavourable interventions in catchment conditions. All anthropogenic actions, often lacking ecological awareness, lead to an increase in catchment vulnerability by supplying biogenic loads to the lake. An example of such actions may be the uncontrolled development of tourism, illegal sewage discharges, meliorations or agriculture introducing loads of nutrients to lakes. This geoecosystem type is represented by the small, shallow and thus polimictic, Lake Techlinko. The poor ecological state of this reservoir is manifested by the occurrence of a winter oxygen deficit, which indicates substantial oxygen losses in the deep water zone, detected during fieldworks. 
The majority, i.e. 8 analysed lobelia lakes represent the fourth lake geoecosystem type. This is a situation of rapid lake water eutrophication. The cause of such a state is, on the one hand a high catchment vulnerability to the activation of areal runoff, and on the other, the poor resistance of the lake itself due to its natural properties. This means that such a lake is seriously vulnerable to external impact. Lake Otalżyno (vulnerability group 3, resistance category III) is a shallow, polimictic reservoir surrounded by pastures and agricultural land. In the vicinity of its shoreline recreational building development is increasing and dominates on the eastern and western shores. Although indicator plants occur in abundance, the low resistance of the lake to its catchment impact, manifests mainly in very small mean depth of only $1.2 \mathrm{~m}$, leads us to the conclusion that they are under serious threat from more expansive plants. The next three lakes, Jelonek, Brzeżonko and Bieszkowickie reveal a lack of resistance (category IV) to catchment impact (vulnerability group 3). Two of them: Brzeżonko and Jelonek are very small reservoirs (5.9 and 8.4 ha respectively) and very shallow (maximum depth 4.7 and $3.6 \mathrm{~m}$ respectively). The most serious threat to the functioning of these limnic systems comes from intense recreational building development. In the case of Lake Brzeżonko, a negative influence is exerted also by very intensive fishing. In summer, already at a depth of $3 \mathrm{~m}$, there are considerable oxygen shortages (5-10\%), generally not observed in such shallow reservoirs. The effect is the almost complete extinction of the indicator species. At present, only Litorella uniflora occurs there but scarcely. The condition of the indicator species in Lake Jelonek is assessed as good. All three plants occur there quite abundantly. This is the result of the still relatively small quantity of biogenic substances dissolved in water. The performed research indicates that the total phosphorus content (Ptot) does not exceed $0.04 \mathrm{mg} \mathrm{dm}^{-3}$, and the content of all forms of nitrogen (Ntot) does not exceed $1.57 \mathrm{mg} \mathrm{dm}^{-3}$. Relatively good physical-chemical conditions occur also in Lake Bieszkowickie, which, due to a strong tourist population in the summer, is categorised as heavily threatened. The lake is continuously frequented by anglers, who often destroy the shallowest section of the littoral which is rich in indicator plants.

The least favourable natural conditions (lake resistance category IV and catchment vulnerability group 4) characterise the geoecosystems of Lakes Karlikowskie, Sitno, Wysoka and Osowskie. Such a lake geoecosystem type indicates that the rate of natural eutrophication is high, and negative anthropogenic activities (permanent building development in the immediate vicinity of the shoreline) help to accelerate the process. With the exception of Lake Osowskie, in all these lakes indicator plants occur quite abundantly. The greatest threats to the functioning of these lakes are illegal discharges of sewage, growing number of summer houses and permanent buildings, a high concentration of holidaymakers in summer, the destruction of the littoral zone, fishing, hydrotechnical activity (Table 6). Lake Osowskie, as a result of the intensification of housing development, will probably become a reservoir with municipal features. In the case of Lake Wysoka a common phenomenon is the occurrence of cyanobacteria. In 2012 this lake was dammed, which can have a very negative impact on the occurrence of indicator plants as they were deprived of their natural depth zone that they occur in. The lease-holders of Lake Karlikowskie provided information that there were instances of hazardous bacteria occurring in its waters, resulting in a ban on bathing. In the case of Lake Sitno, illegal sewage discharges into its tributaries were a common occurrence.

Table 6. Identification of anthropogenic activities for lakes most endangered with degradation

\begin{tabular}{|l|c|c|c|c|c|c|}
\hline \multirow{2}{*}{ Lake } & \multicolumn{5}{|c|}{ Anthropogenic activities } \\
\cline { 2 - 7 } & $\begin{array}{c}\text { illegal sewage } \\
\text { discharge }\end{array}$ & $\begin{array}{c}\text { littoral de- } \\
\text { struction }\end{array}$ & angling & $\begin{array}{c}\text { new permanent and } \\
\text { summer building } \\
\text { development }\end{array}$ & $\begin{array}{c}\text { tourism and } \\
\text { recreation }\end{array}$ & $\begin{array}{c}\text { hydrotechnical } \\
\text { activity }\end{array}$ \\
\hline Wysoka & $\mathrm{x}$ & $\mathrm{x}$ & $\mathrm{x}$ & $\mathrm{x}$ & $\mathrm{x}$ & $\mathrm{x}$ \\
\hline Osowskie & $\mathrm{x}$ & $\mathrm{x}$ & $\mathrm{x}$ & $\mathrm{x}$ & $\mathrm{x}$ & \\
\hline Karlikowskie & $\mathrm{x}$ & $\mathrm{x}$ & $\mathrm{x}$ & & $\mathrm{x}$ & \\
\hline Sitno & $\mathrm{x}$ & $\mathrm{x}$ & $\mathrm{x}$ & & \\
\hline
\end{tabular}




\section{Conclusion}

The above analysis reveals that the lobelia lakes of the Tricity area are a group of reservoirs poorly resistant to the impact of their catchments. Nevertheless, indicator plants do occur in them relatively abundantly. The short distance from the lakes to the Tricity metropolitan area, and in most cases attractive natural and landscape assets provoke anthropogenic activities. The growing and diverse anthropogenic activity disturbs not only the lake ecosystem but also the catchment of the lake. The undermining of the catchment - lake relationship leads to changes in trophic and biocenotic systems which result in distrophication or eutrophication of lakes. Thus, the introduction of areal legal protection for the lobelia lakes of the Tricity area should be accompanied by actions legally regulating economic, industrial and tourist activity both in the catchments of these lakes but also within the reservoirs. Kraska i Piotrowicz (2000) clearly indicate which norms of actions and legal and behavioural restrictions should be introduced in order to prevent further degradation of the lobelia lakes. The geoecosystems of the lobelia lakes of the Tricity area require immediate and determined steps aimed at covering them with legal protection. Otherwise they will soon have to be given the term which is already present in the literature - of historical lobelia lakes.

\section{Acknowledgements}

The research used in this study was financed from the resources for science of the Ministry of Science and Higher Education within the supervisor research project „Hydrological conditions of the functioning of lobelia lakes of the Tricity area" (MNiSW No 1821/B/P01/2009/37).

\section{References}

Bajkiewicz-Grabowska E., 1981. The influence of the physical geographic environment on the biogenous matter delivery to the lake. Journal of Hydrological Sciences 8(1-4): $63-73$.

Bajkiewicz-Grabowska E., 1983. Ecological characteristics of lakes in North-Eastern Poland versus their trophic gradient. II. Lake catchment areas - physico-geographical environment description of the region and 43 lakes. Ekologia Polska 31(3): 257-286.
Bajkiewicz-Grabowska E., 1985. Struktura fizycznogeograficzna zlewni jako podstawa oceny dostawy materii biogennej do jezior (Effect of the physical geographic environment on the biogenus matter delivery to the lakes). Prace i Studia Geograficzne 7: 65-88.

Bajkiewicz-Grabowska E., 1987. Evaluation of the natural susceptibility of shallow lakes to degradation. GeoJurnal 14: 367-371.

Bajkiewicz-Grabowska E., 2002. Obieg materii w systemach rzeczno-jeziornych (Circulation of matter in river-lake systems). Wydawnictwo UW, Warszawa: 274.

Bajkiewicz-Grabowska E., 2007. Zróżnicowanie geoekosystemów jeziornych ze względu na tempo naturalnej eutrofizacji (Diversity of lake geoecosystems in terms of natural eutrophicaton rate). In: Borowiak D. (ed.), Jeziora Kaszubskiego Parku Krajobrazowego, Badania Limnologiczne Tom 5. Katedra Limnologii UG, Gdańsk: 279 $-291$.

Bajkiewicz-Grabowska E., 2010. Assessment of the ecological state of lakes as proposed by the Polish Limnological Society. Limnological Review 3-4: 105-116.

Bertalanffy von L., 1984. Ogólna teoria systemów (General Systems Theory). PWN, Warszawa: 340.

Bociąg K., 1999. New sites for Isoëtes echinospora (Isoëtacae) in the Pomeranian lakes (NW Poland). Fragmenta Floristica et Geobotanica 44(2), Kraków: 423-427.

Buslenko N.P., Kałasznikow W.W., Kowalenko I.N., 1979. Teoria systemów złożonych (Lectures on the theory of complex systems). PWN, Warszawa: 381.

Chojnicki Z., 1988. Koncepcja terytorialnego systemu społecznego (concept of territorial social system). Przegląd Geograficzny 60(4): 491-510.

Czochański J., 1998. Zagadnienia granic i terytorialności systemów przyrodniczych a koncepcja ich określania w systemach rekreacyjnych (Issues of boundaries and territorial character of natural systems vs concept of determining them in recreational systems). Rocznik Fizycznogeograficzny Uniwersytetu Gdańskiego III. Gdańsk: 59-77.

Gacki T., Szukalski J., 1979. Zróżnicowane geoekologiczne i regionalne oraz problemy antropizacji i ochrony środowiska geograficznego (Geoecological and regional diversity and problems of anthropisation and protection of geographical environment). In: Augustowski B. (ed.), Pojezierze Kaszubskie. GTN-Ossolineum, Gdańsk: 221-253.

Gos K., Bociąg K. 2003. Uzupełnienie do listy jezior lobeliowych w Polsce (Supplement to the list of lobelia lakes in Poland). Badania Fizjograficzne nad Polską Zachodnią Ser. B 52: 151-158.

Kajak Z. 1994. Hydrobiologia. Ekosystemy wód śródlądowych (Hydrobiology. Inlands waters ecosystems). Dział Wydawnictw Filii UW, Białystok: 326.

Kistowski M., 1993. Metoda oceny wielkości potencjału rekreacyjnego na przykładzie Polski północno-wschodniej (Method of assessment of the recreational potential value on the example of north-eastern Poland). In: Pietrzak M. (Ed.), Ekologia krajobrazu w badaniach Terytorialnych Systemów Rekreacyjnych. AWF, Poznań: 53-57.

Kistowski M., 1996. Wpływ struktury środowiska przyrodniczego zlewni na stan czystości jezior na przykładzie wybranych zlewni i jezior Pojezierza Suwalskiego i Równiny Augustowskiej (Impact of the structure of natural environment of catchment on lake cleanness state on the example of selected catchments and lakes of the Suwalskie Lakeland and Augustów Plain). Rocznik Fizycz- 
nogeograficzny Uniwersytetu Gdańskiego I. Gdańsk: 53-87.

Kostrzewski A. (ed.), 1991. Koncepcja programu: Monitoring obiegu materii, kompleksowy monitoring środowiska przyrodniczego $\mathrm{w}$ podstawowych typach geoekosystemów Polski (The concept of the program: Monitoring of the matter circulation, a comprehensive monitoring of the environment in the basic types of geoecosystems in Poland). Komitet Naukowy przy Prezydium PAN "Człowiek i Środowisko", Poznań.

Kostrzewski A., 1993. Geoekosystem obszarów nizinnych. Koncepcja metodologiczna. (Summary: The geoecosystem of lowlands areas a methodological conception). In: A. Kostrzewski (ed.). Geoekosystem obszarów nizinnych. Polska Akademia Nauk, Kom. Nauk. Prez. PAN "Człowiek i Środowisko", Zakład Narodowy im. Ossolińskich, Wrocław, 11-17.

Kraska M., Piotrowicz R., 2000. Jeziora lobeliowe: specyfika, trofia, roślinność oraz zagadnienia ochrony (Lobelian lakes: specifity, trophy, vegetation and problems of the preservation). Ochrona jezior I mokradeł Pomorza Środkowego w świetle przemian naturalnych I zagrożeń cywilizacyjnych. Towarzystwo Ekologiczno-Kulturalne w Bobolicach, Biuletyn 3: 5-27.

Kudelska D., Cydzik D., Soszka H. 1994. Wytyczne monitoringu podstawowego jezior (Recommendations for basic monitoring of lakes). Biblioteka Monitoringu Środowiska. Warszawa: 42.

Pazdro Z., Kozerski B., 1990. Hydrogeologia ogólna (General hydrogeology). Wydawnictwo Geologiczne, Warszawa: 623.

Przewoźniak M., 1985. Przyrodnicze uwarunkowania przestrzennego rozwoju Aglomeracji Gdańskiej (Natural conditions of spatial development of Gdańsk metropolitan area). Zeszyty Naukowe Wydziału BiNoZ UG 13, Gdańsk: 79-91.

Przewoźniak M., 1991. Krajobrazowy system interakcyjny strefy nadmorskiej w Polsce (Landscape interactional system of the coastal zone in Poland). Uniwersytet Gdański, Rozprawy i monografie 172, Gdańsk.
Richling A., 1992. Kompleksowa geografia fizyczna (Complex physical geography). PWN Warszawa: 374 .

Richling A., Lechnio J. (eds), 2005. Z problematyki funkcjonowania krajobrazów nizinnych (Issues of the functioning of lowland landscapes). Wydział Geografii i Studiów Regionalnych UW, Warszawa: 271.

Staszek W., 1999. Wstępne rozpoznanie zróżnicowania hydrochemicznego w geosystemie dolnej części zlewni Borucinki na tle uwarunkowań wodnego obiegu materii (Preliminary identification of hydrochemical diversity in the geosystem of the lower Borucinka catchment against conditions of aquatic matter circulation). Rocznik Fizycznogeograficzny Uniwersytetu Gdańskiego IV. Gdańsk: 71-95.

Szmeja J., 1992. Struktura, organizacja przestrzenna i demografia populacji isoetydów. Studium ekologiczne roślin podwodnych (Structure, spatial organisation and demography of isoetid populations. Ecological studiem of submerged aquatic plants). Wydawnictwo Uniwersytetu Gdańskiego, 175, Gdańsk: 1-137.

Szmeja J., Leszczyńska M., Pietrzak P., 1993. Stan zachowania $\mathrm{i}$ antropogeniczne przemiany jezior lobeliowych $\mathrm{w}$ województwie gdańskim, słupskim i koszalińskim (State of preservation and antropogenic transformations of Lobelia lakes in Gdańsk, Słupsk and Koszalin Voivodeship). Uniwersytet Gdański, Gdańsk: 103. (Mscr, In Polish).

Szmeja J., 1996. Rejestr polskich jezior lobeliowych (Register of Polish lobelia lakes). Fragmenta Floristica Geobotanica Series Polonica 3, Kraków: 347-367.

Szyper H., Zaniewska H. 1984. Zagospodarowanie turystyczne na obszarach pojeziernych (Tourist management in lakeland areas). In: Ochrona jezior. Materiały z konferencji. Bydgoszcz, 26 maja 1983 r. Wydawnictwo SD "Epoka", Warszawa: 75-105.

Wilk-Woźniak E., Kraska M., Piotrowicz R., Klimaszyk P., 2012. Jeziora lobeliowe (Lobelia lakes). In: Mroza W. (ed.), Monitoring siedlisk przyrodniczych - przewodnik metodyczny. Część druga. Biblioteka Monitoringu Środowiska, Warszawa: 114-129. 